\title{
COMPOSITION AND SEASONAL VARIATION IN THE DIET OF THE South American sea lion (Otaria flavescens) from Quequén, Argentina
}

\author{
Amalia A. Suarez ${ }^{1}$, Daniela Sanfelice², Marcelo H. Cassini³ and Humberto Luis Cappozzo ${ }^{1 *}$
}

\begin{abstract}
Diet seasonality in South American sea lions, Otaria flavescens, was studied using 252 scats from a male-exclusive

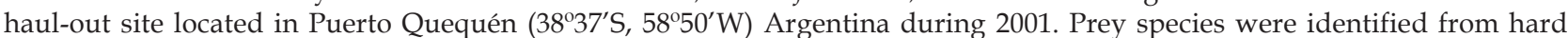
remains and their relative importance was assessed considering frequency of occurrence, abundance and biomass. The main prey consumed by sea lions were teleost fish ( 20 species), followed by cephalopods (four species) and crustaceans. The raneya, Raneya fluminensis, was the most frequent prey year-round, and the most abundant in autumn and winter. The Argentine anchovy, Engraulis anchoita, and the stripped weakfish, Cynoscion guatucupa, were the most abundant prey in spring and summer, respectively. Seasonal differences in the sizes consumed were only found for C. guatucupa. The sea lions from Puerto Quequén showed a diverse diet, mainly feeding on demersal and pelagic prey. Our study fills a geographical gap on the seasonal variation of the diet of South American sea lions. Two main patterns emerged from studies conducted along the geographic range of the species: (1) O. flavescens is a generalist and opportunist feeder, preying on a wide range of species; mainly those of pelagic and demersal habits, (2) South American sea lions change the frequency and/or specific composition of their diet seasonally, possibly as a result of changes in the relative availability of each species in the environment.
\end{abstract}

Resumen: La variación estacional en la dieta del león marino de América del Sur, Otaria flavescens, fue estudiada a partir de 252 heces recolectadas en una colonia no reproductiva de machos localizada en Puerto Quequén $\left(38^{\circ} 37^{\prime} \mathrm{S}, 58^{\circ} 50^{\prime} \mathrm{O}\right)$ Argentina durante el año 2001. Las presas fueron identificadas a nivel de especie a partir de restos duros y su importancia relativa fue evaluada a partir del cálculo de la frecuencia de ocurrencia, la abundancia y la biomasa. Las principales presas consumidas por los leones marinos fueron peces (20 especies), cefalópodos (cuatro especies) y crustáceos. La raneya, Raneya fluminensis, fue la presa más frecuente durante todo el año y la más abundante en otoño e invierno. La anchoíta, Engraulis anchoita, y la pescadilla de red, Cynoscion guatucupa, fueron las presas mas abundantes en primavera y verano respectivamente. Diferencias estacionales en las tallas de las presas consumidas se encontraron sólo en C. guatucupa. Los leones marinos de Puerto Quequén muestran una dieta diversa, consumiendo principalmente especies demersales y pelágicas. Nuestro estudio completa un espacio geográfico con datos sobre la dieta y contribuye al estudio de la variación estacional de la misma en los leones marinos de América del Sur. Así, se completan los estudios a lo largo de casi todo el rango de distribución geográfica. Dos conclusiones principales surgen a partir del presente estudio: (1) O. flavescens es un predador generalista y oportunista que consume un amplio rango de especies, principalmente aquellas de hábitos pelágico y demersal, (2) Los leones marinos de América del Sur cambian la frecuencia y / o la composición especifica de la dieta en forma estacional. Estos cambios están determinados por la disponibilidad relativa de cada especie en el medio, capturando principalmente aquellas especies presas más abundantes.

Keywords: Otaria flavescens, diet, seasonality, Puerto Quequén, Argentina

\section{Introduction}

The South American sea lion, Otaria flavescens, is widely distributed along the Atlantic and Pacific coasts of South America, from Torres in southern Brazil to Cape Horn in the extreme south of the Atlantic coastline, and from Cape Horn to Zorritos in northern Peru, in the Pacific (Vaz-Ferreira, 1982; Cappozzo, 2002). On the Atlantic coast, there are two distinct areas with breeding activity: (1) along the coast of Uruguay at Isla de Lobos $\left(35^{\circ} 02^{\prime} \mathrm{S}\right.$, $\left.52^{\circ} 55^{\prime} \mathrm{W}\right)$, Cabo Polonio ( $\left.34^{\circ} 24^{\prime} \mathrm{S}, 53^{\circ} 46^{\prime} \mathrm{W}\right)$, and La

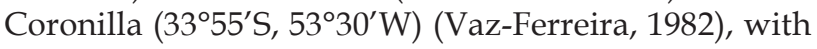
an estimated total of 15,000 individuals; and (2) along the Patagonian coast, from Punta Bermeja $\left(41^{\circ} 08^{\prime} \mathrm{S}\right.$, $\left.63^{\circ} 04^{\prime} \mathrm{W}\right)$ to Tierra del Fuego $\left(54^{\circ} 48^{\prime} \mathrm{S}, 65^{\circ} 15^{\prime} \mathrm{W}\right)$, in 31 colonies with a total of approximately 80,000 individuals (Reyes et al., 1999; Dans et al., 2004; Schiavini et al., 2004). Fifty-two non-breeding colonies are also found in this
Patagonian area. Between Uruguay and Patagonia, there is a gap of 1,000 kilometers that corresponds mainly to the coast of Buenos Aires province, where only two small male colonies are found at Mar del Plata $\left(38^{\circ} 00^{\prime} \mathrm{S}\right.$, $\left.57^{\circ} 33^{\prime} \mathrm{W}\right)$ and Quequén (38 $\left.32^{\prime} \mathrm{S}, 5^{\circ} 42^{\prime} \mathrm{W}\right)$ harbours (Rodriguez, 1996; Szapkievich et al., 1999).

Otaria has no special conservation status at the IUCN (World Conservation Union) or CITES (Convention on International Trade in Endangered Species of Wild Flora and Fauna) and is considered a minor concern species. However, since Otaria populations face a critical situation almost throughout their range, the Government of Peru has proposed to include them in Appendix II of CITES (UNEP, 20024). Only in Argentina are their numbers increasing (Dans et al., 2004). In Peru, the population declined from 144,000 to 28,000 during the 1997-98 El Niño event (Arias-Schreiber Rivas, 1998; Soto et al., 2004). The Malvinas' (Falklands') population

\footnotetext{
${ }^{1}$ Estación Hidrobiológica de Puerto Quequén - Museo Argentino de Ciencias Naturales (CONICET). Av. Á.Gallardo 470, C1405DJR, Buenos Aires, Argentina.

${ }^{2}$ Universidade Federal do Rio Grande do Sul, Instituto de Biociências, Departamento de Zoología. Porto Alegre, RS Brasil.

${ }^{3}$ Universidad de Luján, Departamento de Ciencias Básicas. Rutas 5 y 7, 6700 Luján, Prov. Buenos Aires, Argentina.

* Corresponding author, e-mail: cappozzo@macn.gov.ar.

${ }^{4}$ UNEP (2002) Proposal for inclusion of species on the Appendices of the Convention on the Conservation of Migratory Species of Wild Animals, UNEP World Conservation Monitoring Centre, 8 pp. www.wcmc.org.uk/cms/cop7/species.proposals.
} 
decreased from 380,000 around 1937 to less than 6,000 in 1965 (Thompson et al., 2005). In Uruguay, the population has decreased at a rate of $6 \%$ per year (Páez, $\left.1996^{5}\right)$. There are no systematic statistics for Chile (UNEP, 2002).

The main threats for Otaria are direct killing by fishermen, potential competition with fisheries, and habitat destruction (Northridge, 1984; 1992; Wickens, 1995; UNEP, 2002). Intentional killings are a main threat even as the species is protected in most countries. The main reasons are not only that the fishery industry perceives sea lions as competitors, but also because hunting can be a lucrative activity. The development of industrial fishing in South American seas endangers the pelagic resources upon which sea lions depend (Dans et al., 2003).

Interactions between fishery and sea lions can be classified as direct or operational and indirect or ecological (biological) (Northridge, 1984; 1992; Wickens, 1995). The first kind of interaction implies direct damages for both parts and has been studied in Argentina (Corcuera et al., 1994; Crespo et al., 1994, 1997; Dans et al.; 2003). Sea lions may be killed or die accidentally entangled in the nets. Fisheries suffer net damages and partial harvest losses (Northridge, 1984; Crespo et al., 1994). In ecological interactions, the use of the same resources (without interference) results in detriment to both parties. In this particular case, fisheries capture sea lion prey and sea lions may consume commercial target species.

There are two main types of research strategies to evaluate the two types of competition between sea lions and fisheries. A direct method is based on travelling on fishing boats and counting the number of fishes damaged or consumed by sea lions directly from the net (operational interaction) (Szteren and Páez, 2002). Such method allows for the estimation of the economic loss in catches (commercial target species) or gear damage by sea lions (Northridge, 1984; 1992). An indirect method consists in studying diet composition (from stomach contents and scats) and analyzing the degree of overlap between sea lion prey preferences and commercial species of fish and other marine species. Food habits studies offer valuable information about biological interactions between sea lions and fisheries (Harwood and Croxall, 1988; Daneri and Carlini, 1999; Koen Alonso et al., 2000, Naya et al., 2002; Szteren et al., 2004).
The diet of South American sea lions has been studied in south Brazil (Oliveira, 1995), in Chile (GeorgeNascimento et al., 1985, reviewed by Siefield, 1999), in Uruguay (Szteren and Páez, 2002; Steren et al. 2004), and in Patagonia, Argentina (Rivero et al., 19996; Koen Alonso et al., 2000). South American sea lions feed on a wide variety of prey, mainly teleost fish, cephalopods, and crustaceans (Vaz-Ferreira, 1982; George-Nascimento et al., 1985; Koen Alonso et al., 2000, Trites and Soto, 20047), some of which are important to commercial fisheries (Daneri and Carlini, 1999; Koen Alonso et al., 2000, Naya et al., 2002; Soto et al., 2004).

The objectives of this study were: (1) report on the diet composition of sea lions in one of main fishery harbors of Argentina, (2) analyze the seasonal changes in prey utilization through scat analyses, and (3) compare the diet in this region with that of other areas of sea lion distribution.

\section{Material and Methods}

\section{Study area}

The present study was carried out in Puerto Quequén ( $\left.38^{\circ} 37^{\prime} \mathrm{S}, 58^{\circ} 50^{\prime} \mathrm{W}\right)$ (Figure 1), Buenos Aires province, where a non-breeding rookery of Otaria flavescens males (mostly adults and sub-adults) exists. This rookery has a seasonal variation in number, between 86 and 180 individuals, with lower numbers during summer when some individuals move to the reproductive colonies in Uruguay and northern Patagonia, Argentina (Rodríguez, 1996; Pérez and Cappozzo, 20028; Rodriguez et al., in press). A coastal fleet of around 20 vessels, employing a diverse set of fishing gears (e.g. bottom trawls, gillnet and midwater trawls), operates from this port.

\section{Methodology}

Scats were collected in February $2001(\mathrm{n}=48)$, May 2001 ( $\mathrm{n}=75)$, July $2001(\mathrm{n}=75)$ and November 2001 ( $\mathrm{n}=54$ ) when 34-58, 56-170, 54-117 and 59-91 sea lions were present, respectively. Samples were taken during a one-week period in all seasons. They were preserved in $70 \%$ ethanol and brought to the laboratory for examination. Hard remains were recovered using sieves of different mesh size $(0.5$ and $0.3 \mathrm{~mm}$ ) and rinsing water.

\footnotetext{
${ }^{5}$ Páez, E. (1996) Simulaciones estocásticas en la población de Otaria flavescens en Uruguay. Page 116 in Abstracts, VII Reunión de Especialistas en Mamíferos Acuáticos de América del Sur, Viña del Mar, Chile.

${ }^{6}$ Rivero L., Bastida R., Rodríguez D. and Westergaard G. (1999). Hábitos tróficos de los lobos marinos de un pelo (Otaria flavescens) en el apostadero de Puerto Quequén, Argentina. $8^{\circ}$ Congreso Latinoamericano de Ciencias del Mar, Resumen ampliado: 265 - 266, Trujillo, Peru.

${ }^{7}$ Trites, A. W. and Soto K. H. (2004) A global comparative analysis of sea lions diets. Page 49 in Abstracts, 22nd. Wakefield Fisheries Symposium, Anchorage, Alaska, USA.

${ }^{8}$ Pérez, F. and Cappozzo, H. L. (2002) Análisis de la dinámica circadiana del apostadero no reproductivo del lobo marino de un pelo, Otaria flavescens, en Puerto Quequén, Argentina. In Abstracts, 10RT y $4^{\circ}$ Congreso SOLAMAC, 14 - 19 DE Octubre, Valdivia, Chile.
} 


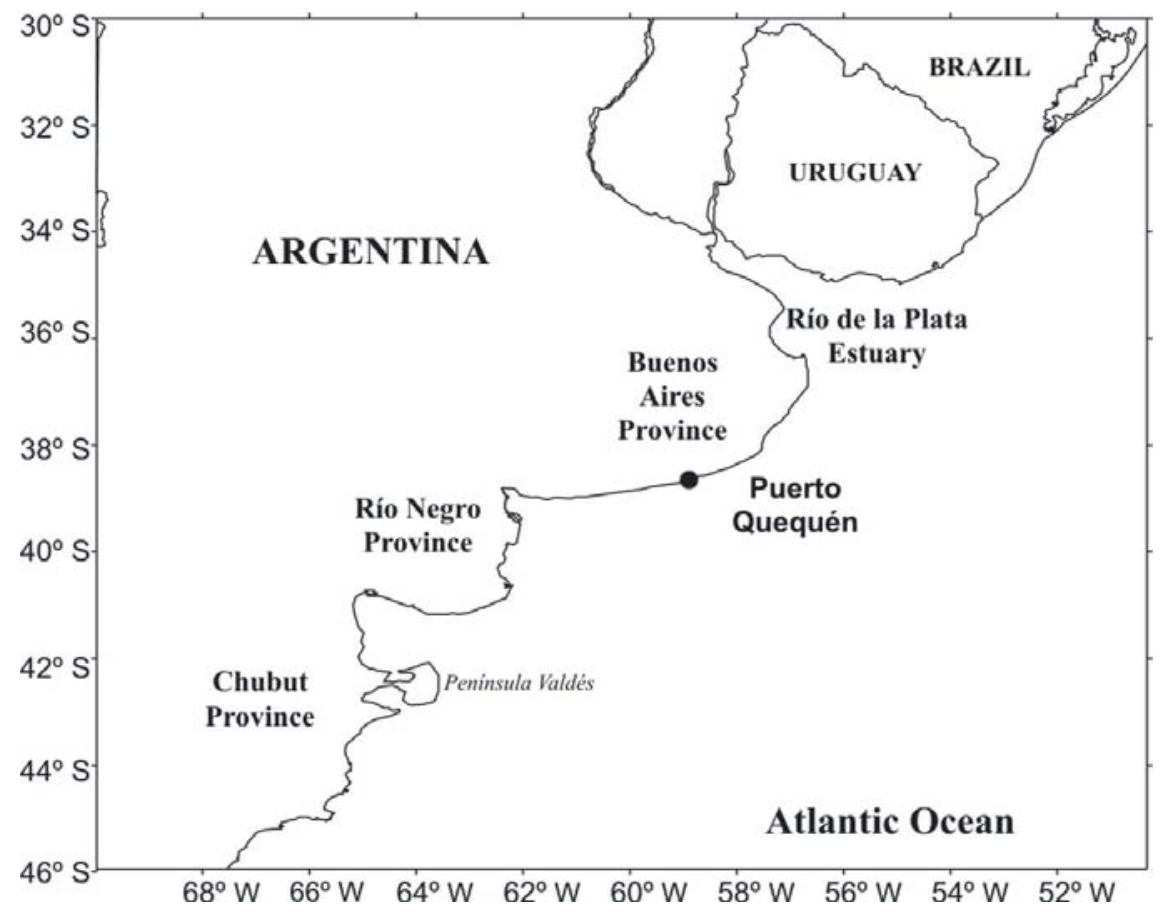

Figure 1. Study area at Puerto Quequén, Argentina.

Fish otoliths and cephalopod beaks were used for prey identification by comparison with available catalogues (Torno, 1976; Volpedo, 1993; Volpedo and Echeverría, 2000), published photographs (Brakoniecki, 1984; Pineda et al., 1996) and our own reference collections (Laboratorio de Ecología y Comportamiento de Mamíferos Marinos, Museo Argentino de Ciencias Naturales, Buenos Aires, Argentina). Identification to species level was made wherever possible. The relative importance of prey species in each season was evaluated using the index of relative importance (IRI) (Pinkas et al., 1971), calculated as:

$$
\mathrm{IRI}=(\% \mathrm{~N}+\% \mathrm{~W}) \% \mathrm{FO},
$$

where $\% \mathrm{FO}$ is the percentage of scats containing an otolith or a beak of the species, the numerical abundance $(\% \mathrm{~N})$ is calculated as the percentage of otoliths or beaks of each taxa within the total number of otoliths and beaks, and $\mathrm{W} \%$ is the wet mass.

Sizes and weights of consumed prey were estimated for the main fish species using regressions between otolith and total length and between length and wet mass (Antúnez, 1983; Baldás, 1997; Koen Alonso et al., 2000). In some cases, we assumed that regressions available for Patagonian species would be also applicable to northern ones. Only complete otoliths with little or no erosion were considered for this analysis.

Data were analyzed following Zar (1996). Statistical tests used are given in the text. Seasonal differences in frequency of occurrence were tested by using the $X^{2}$ test and seasonal differences in length were evaluated using ANOVA test.

\section{Results}

\section{Annual diet composition}

Hard remains were found in $82 \%$ of all scats collected (207 of 252), and 24 prey species were identified (teleost fish and cephalopods) (Table 1). Fish remains (bones, eye lenses, scales and otoliths) occurred in $96.6 \%$ ( $n=$ 199 ) of the scats containing hard remains. From 168 scats, 1,663 otoliths were recovered and 20 fish species identified (Table 1).

Raneya fluminensis (raneya, a species of cusk eel) was the most abundant prey $(\mathrm{n}=522 ; 30.4 \%)$, followed by Cynoscion guatucupa (striped weakfish) ( $\mathrm{n}=230)$, Engraulis anchoita (Argentine anchovy) $(\mathrm{n}=222)$ and Trachurus lathami (horse mackerel) ( $n=178)$; all together, these four species represented over $65 \%$ of the otoliths retrieved (Table 1). The reminder of the fish species were found in lower percentages $(<3.5 \%$ in number).

Raneya fluminensis occurred in $49.3 \%$ of the scats, followed by Trachurus lathami, Cynoscion guatucupa, Etropus longimanus (flounder), Pseudopercis semifasciata (Brazilian sandperch) and Engraulis anchoita (Table 1). Cephalopods (beaks and eye lenses) occurred in $17.8 \%$ of the total scats with hard remains, and were represented by two species of squid: Illex argentinus (Argentine shortfin squid) and Loligo sanpaulensis (South American long-fin squid), and two species of octopus: Eledone massyae (combed octopus) and Octopus tehuelchus (Tehuelche octopus) (Table 1).

Crustaceans appeared in $11 \%$ of the scats that presented hard remains. 
Table 1. Prey composition of Otaria flavescens from Quequén, Argentina. Number of otoliths (n), frequency of occurrence (F) and percent frequency $(\% \mathrm{FO})$ of fish and cephalopods.

\begin{tabular}{|c|c|c|c|c|c|}
\hline \multirow{2}{*}{\multicolumn{2}{|c|}{ TELEOST FISH }} & $\mathrm{n}$ & $\%$ n & $\mathrm{F}$ & $\% \mathrm{FO}$ \\
\hline & & & & & \\
\hline & Raneya fluminensis & 522 & 30.44 & 102 & 49.28 \\
\hline & Carangidae & & & & \\
\hline & Trachurus lathami & 178 & 10.38 & 51 & 24.64 \\
\hline & Sciaenidae & & & & \\
\hline & Cynoscion guatucupa* & 230 & 13.41 & 35 & 16.91 \\
\hline & Umbrina canosai & 45 & 2.62 & 18 & 8.70 \\
\hline & Micropogonias furnieri* & 3 & 0.17 & 3 & 1.45 \\
\hline & Engraulidae & & & & \\
\hline & Engraulis anchoita* & 222 & 12.94 & 21 & 10.14 \\
\hline & Congridae & & & & \\
\hline & Conger orbignyanus & 24 & 1.40 & 11 & 5.31 \\
\hline & Pinguipidae & & & & \\
\hline & Pseudopercis semifasciata* & 55 & 3.21 & 23 & 11.11 \\
\hline & Paralichthyidae & & & & \\
\hline & Etropus longimanus* & 57 & 3.32 & 25 & 12.08 \\
\hline & Xystreurys rasile & 11 & 0.64 & 6 & 2.90 \\
\hline & Paralichthys isosceles* & 15 & 0.87 & 9 & 4.35 \\
\hline & Paralichthys patagonicus* & 11 & 0.64 & 7 & 3.38 \\
\hline & Unidentified & 15 & 0.87 & 8 & 3.86 \\
\hline & Batrachoididae & & & & \\
\hline & Porichthys porosissimus & 56 & 3.27 & 9 & 4.35 \\
\hline & Triglidae & & & & \\
\hline & Prionotus nudigula & 8 & 0.47 & 5 & 2.42 \\
\hline & Merlucciidae & & & & \\
\hline & Merluccius hubbsi* & 21 & 1.22 & 17 & 8.21 \\
\hline & Percophidae & & & & \\
\hline & Percophis brasiliensis & 21 & 1.22 & 15 & 7.25 \\
\hline & Sparidae & & & & \\
\hline & Sparus pagrus & 3 & 0.17 & 3 & 1.45 \\
\hline & Gadidae & & & & \\
\hline & Urophycis brasiliensis* & 1 & 0.06 & 1 & 0.48 \\
\hline & Serranidae & & & & \\
\hline & Acanthistius brasilianus* & 1 & 0.06 & 1 & 0.48 \\
\hline & Stromateidae & & & & \\
\hline & Stromateus brasiliensis & 1 & 0.06 & 1 & 0.48 \\
\hline & Unidentified otoliths & 163 & 9.50 & 63 & 30.43 \\
\hline
\end{tabular}

\section{CEPHALOPODS}

\begin{tabular}{|c|c|c|c|c|}
\hline $\begin{array}{l}\text { Ommastrephidae } \\
\text { Illex argentinus* }\end{array}$ & 9 & 0.52 & 7 & 3.38 \\
\hline \multicolumn{5}{|l|}{ Loliginidae } \\
\hline Loligo sanpaulensis* & 25 & 1.46 & 14 & 6.76 \\
\hline \multicolumn{5}{|l|}{ Octopodidae } \\
\hline Octopus tehuelchus* & 9 & 0.52 & 8 & 3.86 \\
\hline Eledone massyae* & 7 & 0.41 & 5 & 2.42 \\
\hline Unidentified beaks & 2 & 0.12 & 2 & 0.97 \\
\hline Total cephalopods & 52 & 3.03 & 37 & 17.87 \\
\hline
\end{tabular}

(*) Commercial species in Puerto Quequén. 
Seasonal diet composition

In autumn, 368 otoliths of 10 different species were collected from 43 scats. Raneya fluminensis was the most frequent fish prey, followed by Trachurus lathami, Cynoscion guatucupa and Umbrina canosai (Argentine croaker). The most abundant species was Raneya fluminensis, which together with Cynoscion guatucupa accounted for the $65 \%$ of all otoliths retrieved (see Table 2). R. fluminensis was the most important fish prey by reconstructed biomass (\% IRI= 79.7) (Table 2 ).

Six beaks were recovered from scats and all four cephalopod species were present. Octopus tehuelchus was the most frequently found cephalopod species.

In winter, 355 otoliths of 17 species were recovered from 45 of the 60 scats examined. $R$. fluminensis was again the most frequent and abundant prey and together with C. guatucupa and T. lathami accounted for more than $50 \%$ of the total otoliths. Thirteen beaks of cephalopods were recovered from 10 scats and the same four species were present. The most important fish species in this season was $R$. fluminensis (\% IRI= 80.7). Illex argentinus was the most frequent and abundant within cephalopod prey in this season (Table 2).

In spring, 691 otoliths of 15 different species were retrieved from 51 of the 54 available scat samples. The three most frequent species were $R$. fluminensis, T. lathami and E. anchoita.

Engraulis anchoita was numerically the most important prey species, followed by R. fluminensis and T. lathami, which together accounted for more than $65 \%$ of the total otoliths retrieved. R. fluminensis was the most important prey by biomass $(\% \mathrm{IRI}=51.9)$ together with E. anchoita (\% IRI=39.2) (Table 2).

Thirty-two beaks were collected from 20 scats $(\mathrm{FO}=$ $37 \%$ ) and all four cephalopod species were present. Loligo sanpaulensis was the most frequent species, appearing in $60 \%$ of the scats with cephalopods and accounting for $69 \%$ of the total number of beaks in this season.

In summer, 40 of 48 scats presented hard remains, 246 otoliths were retrieved from 29 scats and nine fish species identified. $R$. fluminensis was the most frequent species, followed in importance by $C$. guatucupa, Merluccius hubbsi and E. longimanus. C. guatucupa was the most abundant and important prey, followed by R. fluminensis (Table 2).

Seasonal differences in frequency of occurrence were found in T. lathami $\left(x^{2}=27.32 \mathrm{df}=3 ; \mathrm{p}<0.01\right)$, with the lowest values occurring during summer, and $P$. semifasciata $\left(x^{2}=12.72 \mathrm{df}=3 ; \mathrm{p}<0.01\right)$ with the highest frequency in spring. On the other hand, $R$. fluminensis and C. guatucupa did not present significant differences among seasons $\left(X^{2}=2.66 \mathrm{df}=3 ; \mathrm{p}>0.1\right.$ and $X^{2}=4.58 \mathrm{df}$ $=3 ; \mathrm{p}>0.1$, respectively).

\section{Fish sizes}

Seasonal differences in length of the main fish species (i.e. those most abundant and present at least in two seasons) were calculated from otoliths with little or no erosion. Size frequency distributions of the main prey species are shown in Figures 2-5. No significant differences were found for T. lathami (ANOVA, $\mathrm{df}=2$, $\mathrm{P}>0.1$ ) (Figure 2) or Raneya fluminensis (ANOVA, $\mathrm{df}=$ $3, \mathrm{P}>0.05)$ (Figure 3). Seasonal differences were found for C. guatucupa size classes (ANOVA, df = 3, P < 0.05) (Figure 4), with the smallest fish being consumed in autumn. The mean length for E. anchoita was $147.7 \pm$ $12.6 \mathrm{~mm}$ in spring (Figure 5, Table 3).

\section{Discussion}

The present study shows that $O$. flavescens consumes a wide variety of species, with teleost fish being the most important type of prey (Raneya fluminensis was the most frequent and abundant), followed by cephalopods and crustaceans. The prey consumed were mainly pelagic and demersal, although benthic species were also found. Of the six cephalopod species cited for the province of Buenos Aires (Castellanos, 1970; Rios, 1994; Cousseau, 1997; Pastorino and Tamini, 2002) only the four most common were present within the total prey identified, Loligo sanpaulensis being the most frequent and abundant in the samples.

Diet analysis showed seasonal variation in some prey species both in number and in frequency of occurrence. This variation is associated with the migratory behavior of each prey and probably with oceanographic changes (water masses and associated zooplankton) (Boltovskoy, 1981), which should determine prey availability in the environment where sea lions feed. Argentine anchovy remains were present in the diet of sea lions only in spring, when this specie migrates from north to south Buenos Aires province to reproduce (Cousseau and Perrota, 1998; Bezzi et al., 2000). The frequency of occurrence of horse mackerel was significantly lower in summer, thus agreeing with a low abundance of this species in the bycatch (the unintended catch taken while targeting particular species) of the coastal boats of bottom trawls that operated in Puerto Quequén in 2001 (Tamini, 2001). In spring, when the adult fish move to the coast to feed and to reproduce (Cousseau and Perrota, 1998), a high number of remains of horse mackerel were present in the sea lion diet. The sea lions diet showed seasonal variation along a year sampling period (during 2001) and some differences were observed with other study conducted in the same area but five years earlier (Rivero et al., 1999). Therefore, the differences in prey consumed by sea lions, even in animals from the same area, could be the result of variability in prey abundance and availability. 


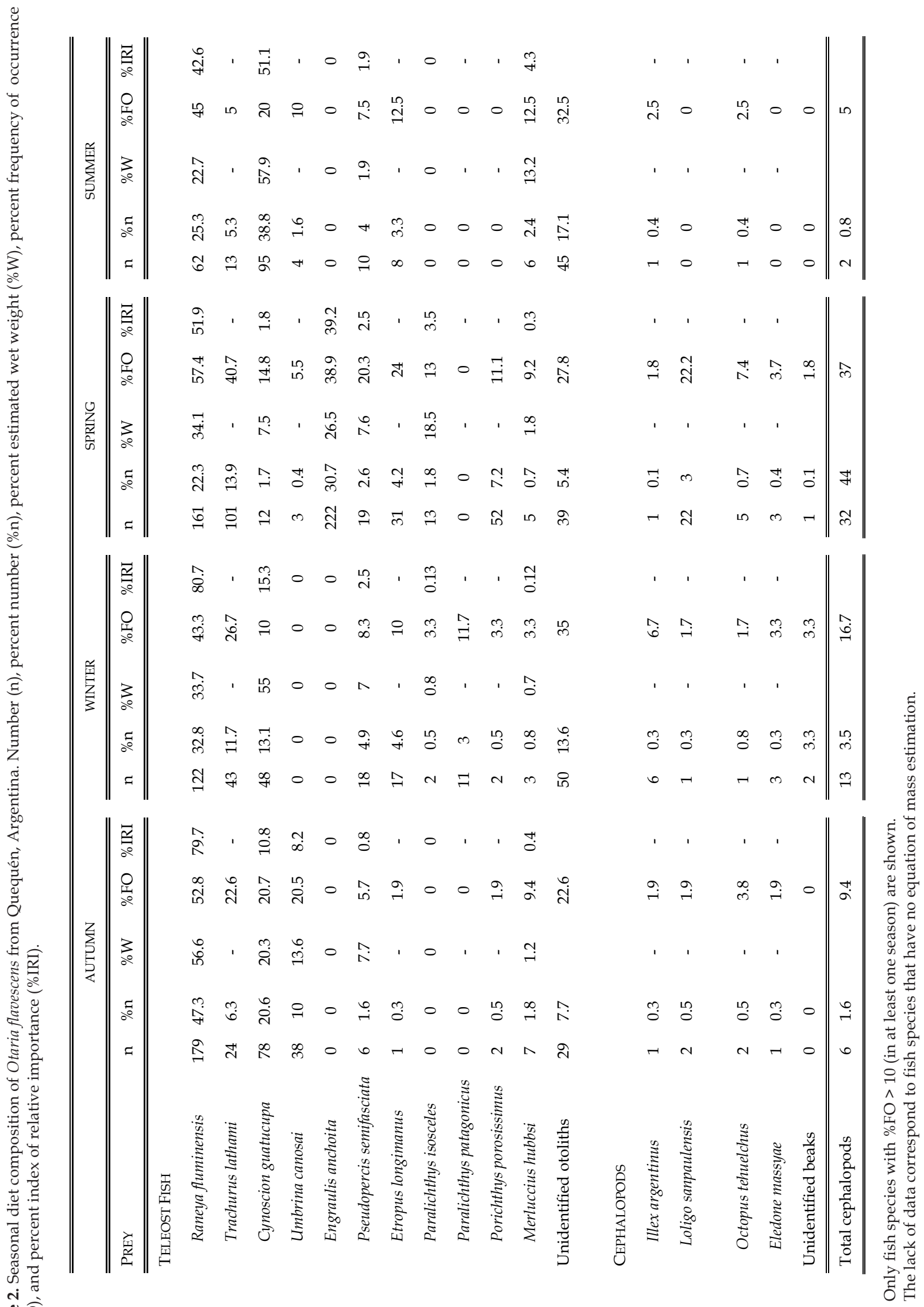




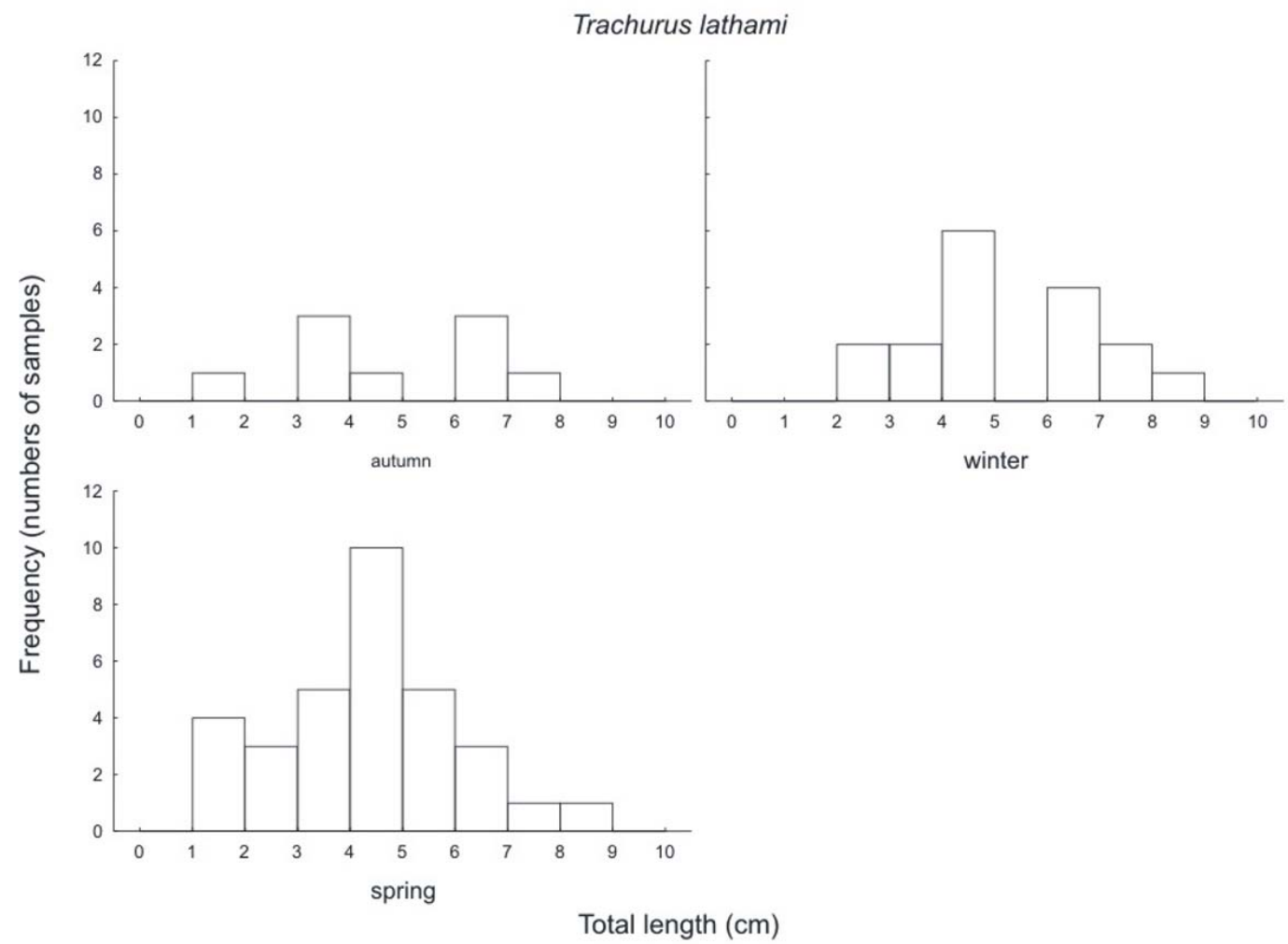

Figure 2. Seasonal length frequency distribution of Trachurus lathami retrieved from scats of Otaria flavescens from Quequén, Argentina.

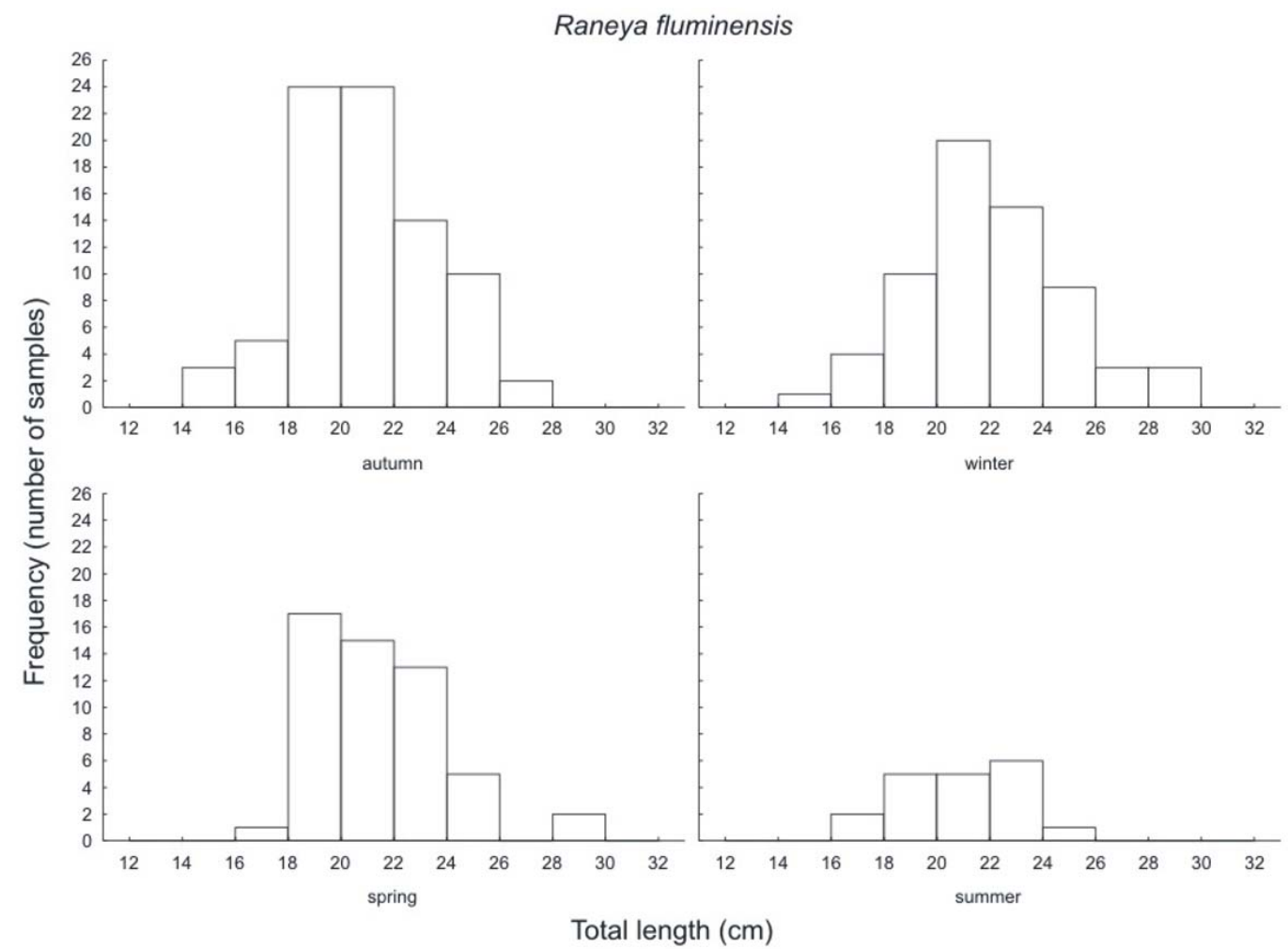

Figure 3. Seasonal length frequency distribution of Raneya fluminensis retrieved from scats of Otaria flavescens from Quequén, Argentina. 


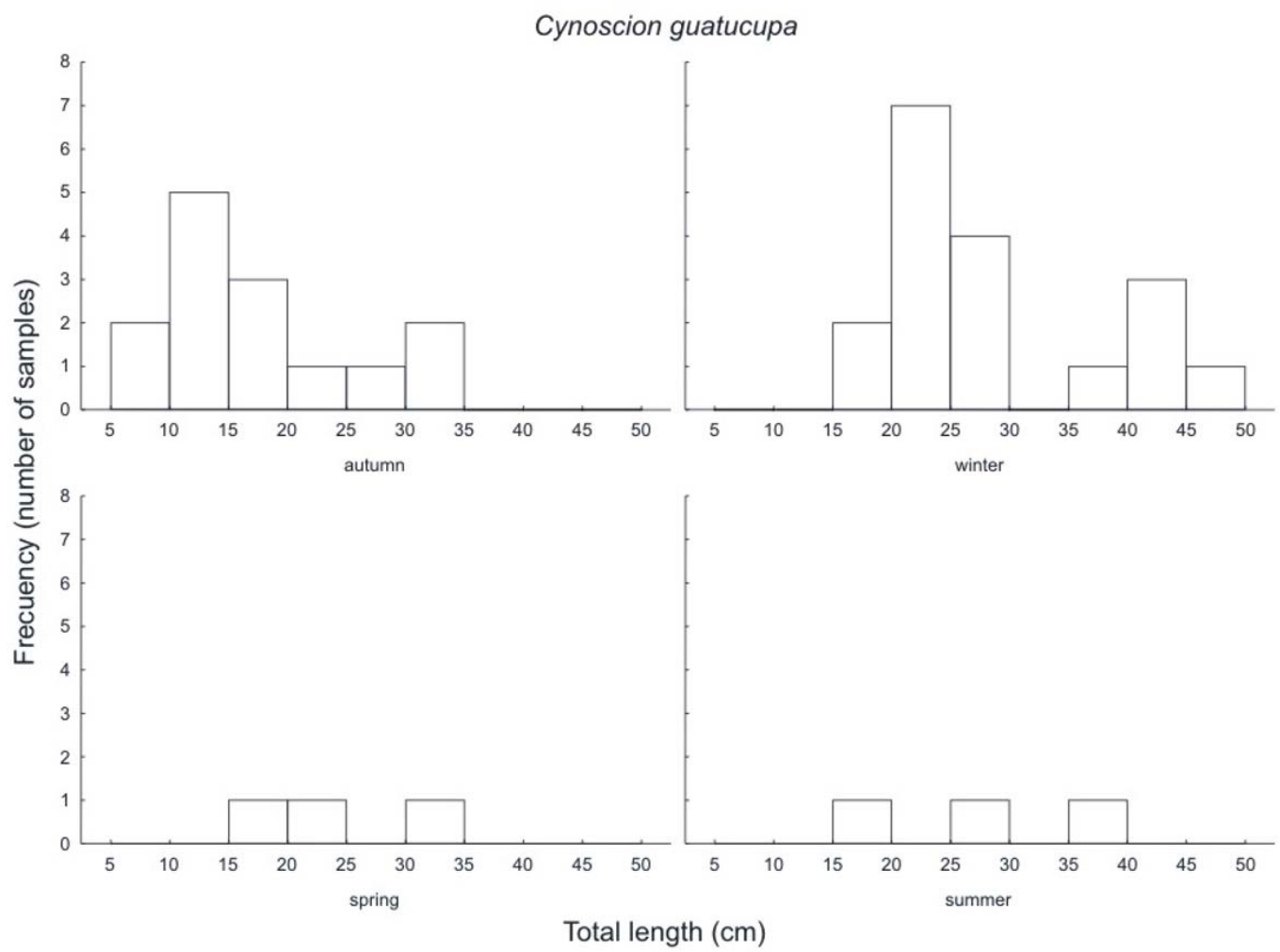

Figure 4. Seasonal length frequency distribution of Cynoscion guatucupa retrieved from scats of Otaria flavescens from Quequén, Argentina.

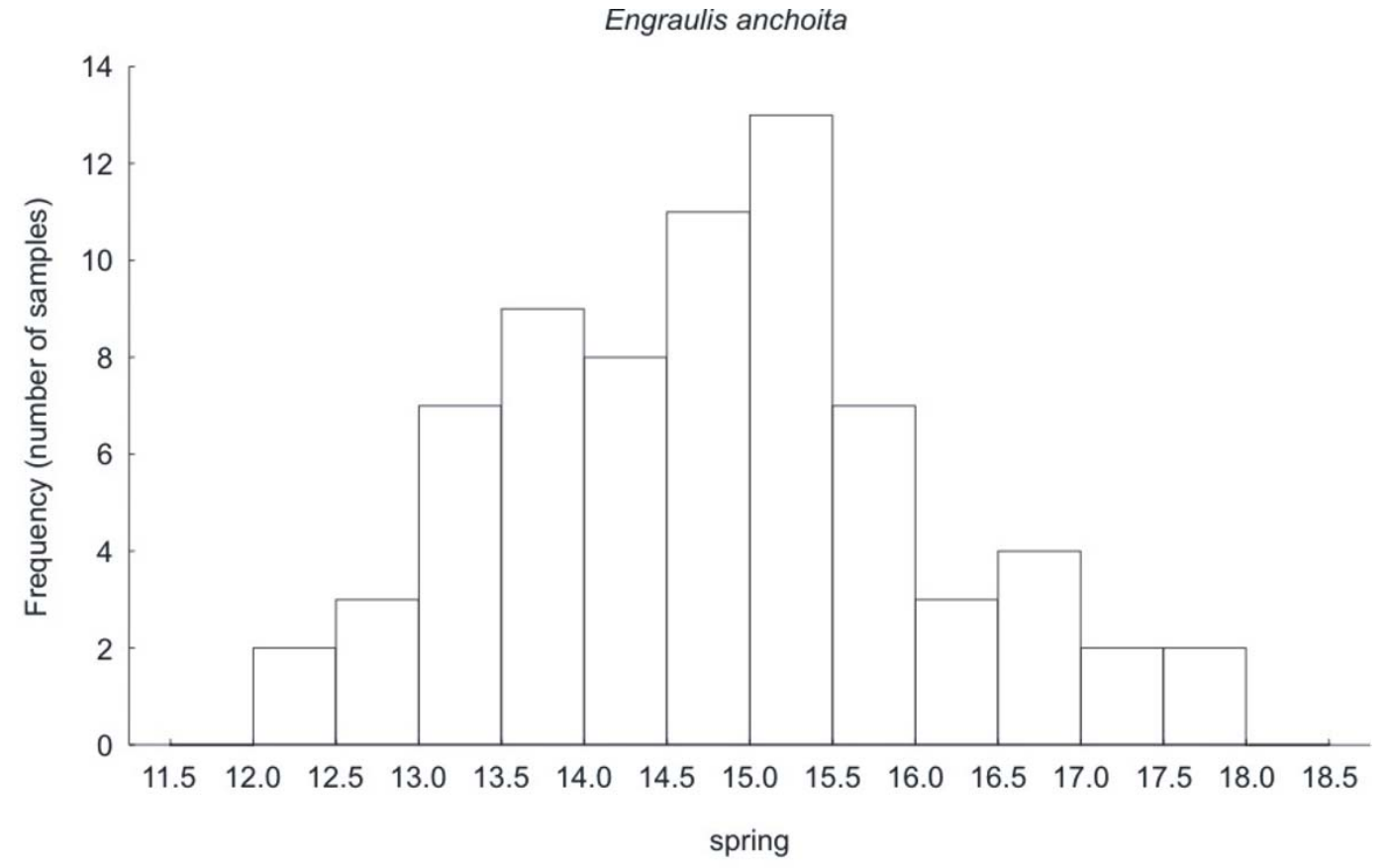

Total length $(\mathrm{cm})$

Figure 5. Length frequency distribution of Engraulis anchoita retrieved from scats of Otaria flavescens from Quequén, Argentina. 
Table 3. Total lengths of the main fish prey species of South American sea lion and commercial size range at Puerto Quequén, Argentina.

\begin{tabular}{lccc}
\hline \hline & $\begin{array}{c}\text { TOTAL LENGTH }(\mathrm{mm}) \\
\text { MEAN } \pm \text { SD }\end{array}$ & $\mathrm{n}^{*}$ & $\begin{array}{c}\text { COMMERCIAL SIZES (mm) } \\
\text { RANGE }\end{array}$ \\
\hline \hline Raneya fluminensis & & & No commercial \\
autumn & $208.9 \pm 26.2$ & 82 & \\
winter & $219.4 \pm 29.3$ & 65 & \\
spring & $214.9 \pm 23.5$ & 53 & \\
summer & $206.6 \pm 20.6$ & 19 & No commercial \\
& & & \\
Trachurus lathami & & & \\
autumn & $48.0 \pm 18.6$ & 9 & 350 - 450 \\
winter & $52.5 \pm 17.9$ & 17 & \\
spring & $42.8 \pm 17.8$ & 32 & \\
& & & \\
Cynoscion guatucupa & & & \\
autumn & $181.8 \pm 83.1$ (a) & 14 & \\
winter & $288.0 \pm 89.0$ (a) & 18 & \\
spring & $239.5 \pm 72.0$ & 3 & \\
summer & $268.0 \pm 93.7$ & 3190 \\
Engraulis anchoita & & & \\
spring & $147.7 \pm 12.6$ & & \\
\hline \hline
\end{tabular}

${ }^{*}$ ) otoliths measured, (a) ANOVA, p $<0.05$

The species composition of the diet of South American sea lions off Patagonia (Koen Alonso et al., 2000) is different from the one found in this work, although in both locations the fish consumed by males are of pelagic and demersal habits. The feeding behavior of sea lions seems opportunistic, as the prey species consumed differ according to their availability in each study region. A similar pattern was found in Chile, where the diet is also based on fishes and cephalopods. On the Chilean southern coast, sea lions tend to consume benthodemersal species of the gadiform (cod) group (GeorgeNascimento et al., 1985). In northern Chile, coastal fish such as Engraulis ringens and Trachinotus paitensis prevailed (Siefield, 1999). In Uruguay, the community of fishes is similar to that of Quequén, our study area; however, Uruguayan sea lions shared only $25 \%$ of the diet with the Otaria of Quequén, and they preferred Anchoa marinii, a prey species that constituted more than half of the summer diet (Naya et al., 2000).

Potential sources of bias were considered in this study. Firstly, sea lions may consume filleted fish discarded from ports. However, as in Puerto Quequén fishermen do not fillet at port, diet estimations do not include any fish heads that the fishermen might have thrown away when filleting at port. Secondly, the use of eroded otoliths may underestimate the actual size of the specimens (Dellinger and Trillmich, 1988; Da Silva and Neilson, 1985). Thirdly, the number of recovered otoliths may also be underestimated (Bowen, 2000). Small otoliths, such as those from Engraulis anchoita, are affected by the erosive effects of the digestive substances of the stomach, not always being eliminated in scats. In addition, cephalopod beaks are resistant to erosion and are retained in the stomach being therefore underestimated when quantifying their number in scats (Bigg and Fawcett, 1985; Harvey and Antonelis, 1994).

The use of scats is a common approach in pinniped dietary studies (Olesiuk et al., 1990, Ochoa and Acuña 1995, Daneri and Carlini 1999, Naya et al. 2002; Szteren et al., 2004). This technique has the advantage that samples are easy to collect and can be obtained in large numbers, without generating any stress to the individuals under study (Carey, 1992). In addition, it is a good alternative for diet studies in small rookeries, where the probability of finding a dead animals is very low, as in the present study. Nevertheless, the disadvantages described above should all be considered.

Of the 20 teleost fish species present in the diet of $O$. flavescens in our study area, $43 \%$ are of commercial interest 
in Puerto Quequén. Of those, only two commercial species (E. anchoita and C. guatucupa) and two noncommercial species ( $R$. fluminensis and T. lathami) were present in numerical abundance greater than $10 \%$; the other species were present in abundance lower than 3.5\%.

The impact of $O$. flavescens on fishery activities varies substantially with the different areas along their distribution (see Crespo, et al. 1994; 1997; Dans, et al. 2003). In Chile, it has been estimated that $O$. flavescens caused the loss of $35 \%$ of the catches in the local artisanal fishery (Sielfeld, 1999). In the Malvinas (Falkland) Islands, Thompson et al. (1998) found no overlap between fish consumed by South American sea lions and those catches landed by the fisheries. Similarly, in Uruguay little overlap was observed between the diet of pinnipeds and artisanal fishery catches (Szteren et al., 2004). In Patagonia, a detailed study described an intermediate context of conflict between pinnipeds and fisheries (Koen Alonso et al., 2000), indicating some overlap but not enough to conclude that competition existed with the fishery. In our study, sea lions showed some overlap with coastal fisheries (bottom trawl fishery) during summer. However, the use of different age classes of the same resource, at different times or spatial locations do not imply less intensity of the interaction (Szteren et al., 2004).

In other areas of the world, sea lions have interacted with fisheries at various levels. In New Zealand, a fishery for squid (Nototodarus sloanii) incidentally catches threatened sea lion species, such as the New Zealand sea lion, Phocarctos hookeri. The bycatch is managed with an annual limit designed to ensure rebuilding of the sea lion population (Breen et al., 2003). Other studies, such as those conducted on the Steller sea lions, Eumetopias jubatus, in Alaska showed a strong positive correlation between diet diversity and sea lion decline in an area: as diet diversity decreased, populations decreased. This suggests that sea lions may require a variety of different prey, perhaps to buffer significant changes in abundance of any single prey (Merrick et al., 1997). The availability of seasonallyabundant, energy-rich prey can be a significant factor for the survival and reproductive success of predator populations (Singler et al., 2004). Higher survival rates of juveniles combined with increased available habitat for newly reproducing individuals could be the key of the recovery of South American sea lion in northern Patagonia. This process may lead to the occupancy of new areas for hauling out and breeding. This hypothesis could explain the higher rates of increase in pups in peripheral areas while reproductive rates remain unchanged (Dans et al., 2004). Pup numbers have been increasing at the rate of $3.4 \%$ per year at the oldest rookeries, but the rate of increase was higher at new rookeries (Dans et al., 2004). The non-reproductive rookeries such as Mar del Plata and Puerto Quequén could be a possible answer to these changes occurring in southern areas.
Our study fills a geographical gap of data on diet and interaction with fisheries of southern sea lions. Together with other studies conducted along other areas of their geographical range, two main patterns emerge: (1) O. flavescens is a generalist and opportunist feeder, preying upon a wide range of species, mainly those of pelagic and demersal habits, (2) sea lions showed seasonality on their diet according to prey availability in the environment, (3) the main prey species were four teleost fishes (two the commercial interest and two non-important ones) and one cephalopod species, (4) One of the most important prey (C. guatucupa) and target species for coastal fisheries was consumed by sea lions on commercial sizes during summer.

\section{Acknowledgments}

We thank Mariano Koen Alonso, Nélio Barros and an anonymous referee for their helpful comments on the manuscript. Victoria Panebianco and Eleonora Bocci provided lab assistance (LECyMM-MACN). José Dato and other fishermen of Puerto Quequén fleet; Roque Bruno, owner of Pescadería "Santa Cecilia" and Jorge Perez helped at the beginning of the investigation. Fundación Antorchas, project FA-13672/1-3; CONICET, project PIP-02193; and project V04B/304 DGUI, Generalitat Valenciana (Valencia, Spain) supported this research.

\section{References}

ARIAS-SCHREIBER, M. AND RIVAS, C. (1998) Distribución, tamaño y estructura de las poblaciones de lobos marinos Arctocephalus australis y Otaria byronia en el litoral peruano en Noviembre 1996 y Marzo 1997. Informe Programa del Instituto del Mar de Perú 73: 17-32.

Antúnez, P. (1983) Estudio del crecimiento en la pescadilla (Cynoscion striatus) de la zona común de pesca ArgentinoUruguaya durante los años 1976-1978. B.Sc. Thesis. Facultad de Humanidades y Ciencias, Universidad de la República. Montevideo, Uruguay. 113 pp.

Baldás, M.I., Pérez-Macri, G., Volpedo, A.V. And EcherverríA, D. (1997) Morfología de la sagitta de peces marinos de la costa bonaerense de la Argentina I: Carangidae, Scianidae, Mullidae. Atlântica, Rio Grande 19: 99-112.

Bezzi, S., Akselman, R. And Boschi, E. (Eds) (2000) Sintesis del estado de las pesquerías marítimas argentinas y de la Cuenca del Plata. Años 1997-1998, con la actualización de 1999. Publicaciones especiales. INIDEP, Mar del Plata, 388 pp.

BigG, M.A. And FAwcett, I. (1985) Two biases in diet determination of northern fur seals (Callorhinus ursinus). Pages 284-291 in Beddington, J.R., Berverton, R.J.H. AND LAVIGnE, D.M. (Eds) Marine Mammals and Fisheries. George Allen \& Unwin, London, England.

Breen, P.A.; Hilborn, R.; Maunder, M.N. and Kim, S.W. (2003) Effects of alternative control rules on the conflict between a fishery and a threatened sea lion (Phocarctos hookeri). Canadian Journal of Fisheries and Aquatic Sciences 60: 527-541. 
Boltovskoy, E. (1981) Masas de agua en el Atlántico Sudoccidental. Pages 227-239 in BoltovsKoy, D. (Ed.) Atlas del zooplancton del Atlántico Sudoccidental y métodos de trabajo con el zooplancton marino. Publicación Española del INIDEP, Mar del Plata, Argentina.

BOWEN, W.D. (2000) Reconstruction of pinniped diets: accounting for complete digestion of otoliths and cephalopods beaks. Canadian Journal of Fishery and Aquatic Science 57: 898-905.

BRAKONIECKI, T.F. (1984) A full description of Loligo sanpaulensis, Brakoniecki, 1984 and a redescription of Loligo gahi D'Orbigny, 1835, two species of squid (Cephalopoda; Myopsida) from the Southwest Atlantic. Bulletin of Marine Science 34(4): 435-448.

CAPpozzo, H.L. (2002) New perspectives on the behavioural ecology of pinnipeds. Pages 243-263 in Evans and RaGa (Eds) Marine Mammals: Biology and Conservation. Kluwer Academic/ Plenum Publishers. New York, NY.

CAReY, P.W. (1992) Fish prey species of the New Zealand fur seal (Arctocephalus forsteri, Lesson). New Zealand Journal of Ecology 16: 41-46.

Castellanos, Z.J.A. de (1970) Catálogo de los moluscos marinos bonaerenses. Anales de la Comisión de Investigaciones Científicas 7: 9-390.

Corcuera, J., Monzón, F., Crespo, E.A., Aguilar, A. and Raga, J.A. (1994) Interactions between marine mammals and the coastal fisheries of Necochea and Claromecó (Buenos Aires Province, Argentina). Report of the International Whaling Commission (Special Issue 15): 283-290.

Cousseau, M.B. and Perrota, R.G. (1998) Peces marinos de Argentina: biología, distribución, pesca. Instituto Nacional de Investigación y Desarrollo Pesquero. Mar del Plata, Argentina.

Cousseau, M.B. (Ed.) (1997) Peces, crustáceos y moluscos registrados en el sector del Atlántico Sudoccidental comprendido entre $34^{\circ}$ y $55^{\circ} \mathrm{S}$, con indicación de las especies de interés pesquero. INIDEP Informe Técnico No 5, 96 p. Mar del Plata, Argentina.

Crespo, E.A., Corcuera, J. and Lopez-Cazorla, A. (1994) Interactions between marine mammals and fisheries in some coastal fishing areas of Argentina. Report of the International Whaling Commission (Special Issue 15): 269-281.

Crespo, E.A., Pedraza, S.N., Dans, S.L., Koen Alonso, M., Reyes, L., García, N.A. And Coscarella, M. (1997) Direct and indirect effects of the highseas fisheries on the marine mammal populations in the Northern and Central Patagonian Coast. Journal of the Northwest Atlantic Fishery Science 22: 1-19.

Da SILVA, J. AND NeILSON, J.D. (1985) Limitations of using otoliths recovered in scats to estimate prey consumption in seals. Canadian Journal of Fisheries and Aquatic Sciences 42: 1439-1442.

Daneri, G.A. AND CARLINI, A.R. (1999) Spring and summer predation on fish by the Antartic fur seal, Arctocephalus gazella, at Kin George Island, South Shetland Islands. Canadian Journal of Zoology 77: 1157-1160.

Dans, S.L., Koen Alonso, M., Crespo, E.A, Pedraza, S.N. And GARCíA, N.A. (2003) Interactions between marine mammals and high seas fisheries in Patagonia under an integrated approach. Pages 100-115 in Gales, N., Hindell, M. And KIRKWOOD, R. (Eds) Marine Mammals: Fisheries, Tourism and Management Issues CSIRO Publishing, Collingwood, Australia.
Dans, S.L., Crespo, E.A., Pedraza, S.N. and Koen-Alonso, M. (2004) Recovery of the South American sea lion (Otaria flavescens) population in northern Patagonia. Canadian Journal of Fisheries and Aquatic Sciences 61: 1681-1690.

Dellinger, T. And Trillmich, F. (1988) Estimating diet composition from scat analysis in otariid seals (Otariidae): is it reliable? Canadian Journal of Zoology 66: 1865-1870.

George-Nascimento, M., Bustamante, R.A. and Oyarzun, R.C. (1985) Feeding ecology of the southern sea lion Otaria flavescens Shaw, 1800: food contents and food selectivity. Marine Ecology Progress Series 21: 135-143.

Harvey, J.T. And Antonelis, G.A. (1994) Biases associated with non-lethal methods of determining the diet of northern elephant seals. Marine Mammal Science 10(2): 178-187.

HaRWOOD, J. AND CROXALl, J.P. (1988) The assessment of competition between seals and commercial fisheries in the northern sea and the Antarctic. Marine Mammal Science 4(1): 13-33.

Koen-Alonso, M., Crespo, E.A., Pedraza, S.N., García, N.G. and Coscarella, M.A. (2000) Food habits of the South American sea lion Otaria flavescens, off Patagonia, Argentina. Fishery Bulletin 98: 250-263.

Merrick, R.L., Chumbley, M.K. And Byrd, G.V. (1997) Diet diversity of Steller sea lions (Eumetopias jubatus) and their population decline in Alaska: a potential relationship. Canadian Journal of Fisheries and Aquatic Sciences 54(6): 1342-1348.

NAYA, D.E., ARIM, M. AND VARGAS, R. (2000) Análisis preliminar de la dieta del lobo marino del sur (Otaria flavescens) en la Isla de Lobos, Uruguay. Boletín de la Sociedad Zoológica del Uruguay 12: 14-21.

NAYA, D.E., ARIM, M. AND VARGas, R. (2002) Diet of South American fur seals (Arctocephalus australis) in Isla de Lobos, Uruguay. Marine Mammal Science 18(3): 734-745.

NoRTHRIDGE, S.P. (1984) World review of interactions between marine mammals and fisheries. FAO Fisheries Technical Paper 251: 194 pp, Rome.

Northridge, S.P. (1992) Actualización del estudio mundial de las interacciones entre los mamíferos marinos y la pesca. FAO Documento Técnico de Pesca 251, Supplement 1, 62 pp., Rome.

OchoA Acuña, H. AND Francis, J.M. (1995) Spring and summer prey of the Juan Fernández fur seal, Arctocephalus philippii. Canadian Journal of Zoology 73: 1444-1452.

Olesiuk, P.F., BigG, M.A., ElLis, G.M., CROCKFord, S.J. AND Wigen, R.J. (1990) An assessment of the feeding habits of harbour seals (Phoca vitulina) in the Strait of Georgia, British Columbia, based on scat analysis. Canadian Technical Report of Fisheries and Aquatic Sciences 1730: 1-135.

OLIVEIRA, L.R. (1995) Estudo da ecologia alimentar das espécies de pinípedes ocorrentes no litoral norte do Rio Grande do Sul, Brasil. B.Sc. Thesis. Universidade Federal do Rio Grande do Sul, Porto Alegre, RS, Brazil. 61pp.

Pastorino, G. And TAmini, L. (2002) Argonauta nodosa Solander, 1786 (Cephalopoda: Argonautidae) in Argentine waters. Journal of Conchology 37(5): 477-482.

PinedA, S.E., Aubone, A. AND BrunetTI, N. (1996) Identificación y morfometría comparada de las mandíbulas de Loligo gahi y Loligo sanpaulensis (Cephalopoda, Loliginidae) del Atlántico Sudoccidental. Revista de Investigación y Desarrollo Pesquero 10: 85-99. 
Pinkas, L., Oliphant, M.S. And Iverson, I.L.K. (1971) Food habits of albacore, bluefin tuna and bonito in California waters. Fishery Bulletin 152: 1-105.

Reyes, L.M., Crespo E.A. And Szapkievich V. (1999) Distribution and population size of the southern sea lion (Otaria flavescens) in central and southern Chubut, Argentina. Marine Mammal Science 15(2): 478-493.

Rıos, E.C. (1994) Seashells of Brazil. Editora da Fundação Universidade do Rio Grande, Rio Grande, Brazil, 311pp.

Rodríguez, D.H. (1996) Biología y ecología de los pinnípedos del sector bonaerense. Ph.D. Thesis. Universidad Nacional de Mar del Plata, Buenos Aires, Argentina, 328pp.

Rodríguez, D.; BASTIDA, R.; CALKINS, D. AND DAVIES, R. (in press) Movements of juvenile southern sea lion in La Plata River Estuary (Argentina - Uruguay) in Sea Lions of the World, Alaska Sea Grant College Program.

Schiavini, A.C., Crespo, E.A. AND Szapkievich, V. (2004) Status of the population of South American sea lion (Otaria flavescens Shaw, 1800) in southern Argentina. Mammalian Biology 69: 108-118.

Sigler, M.F., Womble, J.-N. And Vollenweider, J.J. (2004) Availability to Steller sea lions (Eumetopias jubatus) of a seasonal prey resource: a prespawning aggregation of eulachon (Thaleichthys pacificus). Canadian Journal of Fisheries and Aquatic Sciences 61(8): 1475-1484.

SIELFELD, W. (1999) Estado de conocimiento sobre conservación y preservación de Otaria flavescens (Shaw 1800) y Arctocephalus australis (Zimmerman 1783) en las costas de Chile. Estudios Oceanológicos 18: 81-96.

Szapkievich, V.B., Cappozzo, H.L., Crespo E.A., Bernabeu R.O., Comas, C. AND Mudry, M. (1999) Genetic relatedness in two southern sea lion (Otaria flavescens) rookeries in Southwestern Atlantic. Zeitschrift für Säugetierkunde 64: 1-5.

Szteren, D. And PÁez, E. (2002) Predation by southern sea lions (Otaria flavescens) on artisanal fishing catches in Uruguay. Marine and Freshwater Research 53: 1161-1167.

SZTEREN, D.; NAYA, D.E. AND ARIM, M. (2004) Overlap between pinniped summer diet and artisanal fishery catches in Uruguay.
The Latin American Journal of Aquatic Mammals 3(2): 119-125.

Soto, K.H.; Trites, A.W. And Arias-Schreiber, M. (2004) The effects of prey availability on pup mortality and the timing of birth of South American sea lions (Otaria flavescens) in Peru. Journal of Zoology, London 264: 419-428.

TAmini, L. (2001) Estudio del descarte en la pesca de arrastre de fondo en el área de Puerto Quequén, provincia de Buenos Aires, Argentina. B.Sc. Thesis. Facultad de Ciencias Exactas y Naturales. Universidad de Buenos Aires, Argentina. 63 pp.

Thompson, D., Duck, C.D., McConnell, B.J. And Garrett, J. (1998) Foraging behaviour and diet of lactating females southern sea lions (Otaria flavescens) in the Falkland Islands. Journal of Zoology, London 246: 135-146.

Thompson, D., Strange, I., Riddy, M. And Duck, C.D. (2005) The size and status of the population of southern sea lions Otaria flavescens in the Falkland Islands. Biological Conservation 121: 357-367.

Torno, A.E. (1976) Descripción y comparación de los otolitos de algunas familias de peces de la plataforma argentina. Revista del Museo Argentino de Ciencias Naturales "Bernardino Rivadavia" e Instituto Nacional de Investigación de Ciencias Naturales Tomo XII, n. 4: 3-20.

Vaz-Ferreira, R. (1982) Otaria flavescens (Shaw), South American sea lion. Mammals of the World. FAO Fisheries Series 5(IV): 447-495.

Volpedo, A.V. AND Echeverría, D.D. (2000) Catálogo y claves de otolitos para la identificación de peces del mar Argentino, 1. Peces de importancia económica. Editorial Dunken. Buenos Aires, Argentina. 90 pp.

Volpedo, A.V. (1993) Morfología de los otolitos de peces marinos patagónicos. B.Sc. Thesis, Facultad de Ciencias Exactas y Naturales, Universidad de Buenos Aires, Argentina. 89 pp.

WiCKENS, P.A. (1995) A review of operational interactions between pinnipeds and fisheries. FAO Fisheries Technical Paper 346, 86 pp. Rome.

ZAR, J.H. (1996) Biostatistical Analysis. Prentice Hall. Upper Saddle River, NJ. 